\title{
Evaluation of Genetic and Biochemical Factors in Patients with Acute Coronary Syndrome
}

\section{Evaluación de factores genéticos y bioquímicos en individuos con síndrome coronario agudo}

\author{
Katerina BAstidas 1 \\ Pontificia Universidad Javeriana, Colombia \\ MÓNICA Botero 1 \\ Pontificia Universidad Javeriana, Colombia \\ María Lucía Salamanca 1 \\ Pontificia Universidad Javeriana, Colombia \\ PaOla Ayala-Ramírez 2 \\ Pontificia Universidad Javeriana, Colombia \\ Reggie García-Robles 3 \\ Pontificia Universidad Javeriana, Colombia \\ Martha Bermúdez 2 \\ Pontificia Universidad Javeriana, Colombia
}

\footnotetext{
1 Estudiante de Medicina, Facultad de Medicina Pontificia Universidad Javeriana, Bogotá, D.C, Colombia.

2 Profesora, Instituto de Genética Humana, Facultad de Medicina, Pontificia Universidad Javeriana, Bogotá, D. C., Colombia.

3 Profesor, Departamento de Ciencias Fisiológicas, Facultad de Medicina, Pontificia Universidad Javeriana, Bogotá, D.C, Colombia.
}

Cómo citar: Bastidas K, Botero M, Salamanca ML, Ayala-Ramírez P, García-Robles R, Bermúdez M. Evaluation of genetic and biochemical factors in patients with acute coronary syndrome. Univ Med. 2017;58(2):1-9. doi: https://doi.org/10.11144/Javer iana.umed58-2.egbf

\begin{abstract}
Introduction: The cardiovascular diseases are the principal cause of death worldwide and a public health problem in Colombia. From the cardiac related illnesses, the most frequent is the Acute Coronary Syndrome (ACS). One of its risk factor is high plasma levels of homocysteine. The enzyme Paraoxonase 1 (PON1) hydrolyzes Homocysteine-thiolactone, producing homocysteine, avoiding damage to endothelium related to Homocysteine-thiolactone. Two genetic variants in PON1 gene have been associated with levels of homocysteine and acute coronary syndrome. Objective: to determine the relationship between the polymorphisms Q192R and L55M from gene PON1 and the levels of homocysteine, HDL, apo A-1 and the enzymatic activity of Paraoxonase I in patients who suffered acute coronary syndrome. Methods: sixteen unrelated patients with Acute Coronary Syndrome (ACS) and sixteen healthy controls were enrolled. The paraoxonase activity, levels of homocysteine, HDL and apo A-1 were assessed. The DNA polymorphism analysis was performed using Polymerase Chain Reaction (PCR) and digestion with restriction enzymes. Results: levels of homocysteine are higher in cases $(\mathrm{p}<0.0001)$ and the genotypes 192RR and $\mathrm{QR}$ are associated with higher levels of homocysteine $(p=0.0234)$. Conclusion: polymorphisms in PON1 gene could be related to homocysteine levels in Acute Coronary Syndrome patients.

Keywords

cardiovascular diseases; polymorphism; homocysteine.
\end{abstract}

\section{RESUMEN}


Introducción: Las enfermedades cardiovasculares son la principal causa de muerte mundial y es un problema de salud pública en Colombia. De las enfermedades cardiacas relacionadas, el síndrome coronario agudo es el más frecuente. Uno de sus factores de riesgo son los niveles elevados plasmáticos de homocisteína. La enzima paraoxonasa 1 (PON1) hidroliza homocisteína-tiolactona y la convierte a homocisteína, evitando daño al endotelio, que podría estar relacionado con homocisteína-tiolactona. Dos variantes genéticas en el gen PON1 se han asociado con las concentraciones de homocisteína y el síndrome coronario agudo. Objetivos: Determinar la relación entre los polimorfismos Q192R y L55M del gen PON1 y los niveles de homocisteína, HDL, apo A-1 y la actividad enzimática de la paraoxonasa I en pacientes con síndrome coronario agudo. Métodos: Se estudiaron 16 pacientes no relacionados, con diagnóstico de síndrome coronario agudo y 16 controles sanos. Se evaluó la actividad de la paraoxonasa, cantidades de homocisteína, HDL, Apo A-1. La genotipificación de los polimorfismos Q192R y L55M del gen PON1 se realizó utilizando la técnica reacción en cadena de la polimerasa (PCR) y enzimas de restricción. Resultados: Los resultados mostraron que la homocisteína es mayor en los casos ( $\mathrm{p}<0,0001)$ y que los genotipos 192RR y QR están asociados con altas cantidades de homocisteína $(p=0,0234)$. Conclusiones: Polimorfismos en el gen de PON1 están relacionados con las concentraciones de homocisteína en pacientes con síndrome coronario agudo.

Palabras clave

enfermedades cardiovasculares; polymorphism; homocysteine.

\section{Introduction}

The cardiovascular diseases are the principal cause of death in the developed countries and play an important role in the developing countries [1]. In Colombia, the principal cause of death in people older than 55 years during the last 10 years is the cardiac ischemic disease, even over cancer and violence [2]. From the cardiac related illnesses, the most frequent is the Acute Coronary Syndrome (ACS). This syndrome is composed by different diseases related with the rupture of an atherosclerotic plaque, thrombotic effects and embolization that take place in the coronary arteries, which irrigate the cardiac muscle, producing a hypoperfusion to the heart [1].

The diseases included in this syndrome are classified in two groups, the ACS with elevation of ST and the ACS without ST elevation. The first group includes Acute myocardial infarction with ST elevation and the second group is composed by stable angina, unstable angina and Acute myocardial infarction without ST elevation [3]. When ST elevation is not shown in the electrocardiogram suggests that the occlusion of the artery might be incomplete, that although the flow is reduced there is some blood going through, and nevertheless that zone could suffer ischemia and necrosis. When the elevation is seen it suggests that the artery is occluded entirely and it has greater risk of necrosis [4].

Currently, some risk factors for developing coronary artery disease are known, among them we notice 3 groups: the ones related to lifestyle (smoking, high calories, cholesterol, high fat diet, low vegetables and fruit diet, alcohol abuse, and sedentary lifestyle), the ones related to abnormal conditions (high total cholesterol, high LDL cholesterol, low HDL cholesterol, hypertriglyceridemia, diabetes mellitus, arterial hypertension, obesity and thrombogenic diseases) and the ones related to the person itself (age, gender, family history of coronary disease, and personal history of cardiovascular disease) [5].

Nowadays, new risk factors are being determined, among them high levels of homocysteine (Hcy) have been proposed. Homocysteine is a non-protein amino acid synthesized from a metabolic pathway where methionine, B6 and B12 vitamins and folic acid are involved. It is known now that this amino acid at cellular level has effects on endothelial cells by decreasing the bioavailability of $\mathrm{NO}$, increasing intracellular oxidative stress and triggering other pro-atherogenic mechanisms. Studies have determined that this is an independent risk factor for atherosclerosis, and that it is associated with thromboembolic events [6].

Homocysteine in the body reacts with an enzyme called paraoxonase 1 , coded by PON1 gene. This enzyme has an important activity reducing the oxidized LDL by hydrolyzing lipid peroxides and keeping high levels of HDL. Paraoxonase 1 has the ability of hydrolyzing variety of substrates, one of them 
is homocysteine, and is the only one known to happen naturally, turning Hcy-thiolactone tohomocysteine (HCY). So paraoxonase 1 protects from a form of homocysteine that could cause damage to endothelium [7]. Then, deficiency of the enzyme activity of PON1 could be involved in the development of atherosclerosis. Two of the most frequent genetic variations observed in this phenomenon are the substitution of leucine by methionine at position 55 and glutamine by arginine at the 192 position at the protein. These genetic variants have been studied and it is not clear their role as risk factors for cardiovascular disease [8].

The aim of this project was to determine the relationship between the Q192R and L55M polymorphisms of PON1 gene and the levels of homocysteine, HDL, apo A-1 and the enzymatic activity of Paraoxonase I in patients with acute coronary syndrome.

\section{Material and methods}

\section{Population of study}

A case-control study was performed. The study population was composed by sixteen unrelated patients with ACS and sixteen controls. The patients in the study were diagnosed with Acute Coronary Syndrome and were included in a previous study named "Association between homocysteine, other cardiovascular risk factors and the polymorphisms $699 \mathrm{C} / \mathrm{T}, 1080 \mathrm{C} / \mathrm{T}, 844$ insertion $68 \mathrm{pb}$ from the CBS and $677 \mathrm{C} / \mathrm{T}$ from the MTHFR from patients with Acute coronary syndrome." Patients signed permission, allowing the investigation group to use their samples for complementary studies [9].

The lack of desire to participate in the study and prothrombotic state (antiphospholipid syndrome, LES, hepatic disease, thrombosis and cancer) were the exclusion criteria. The provisions established in the $\mathrm{N}^{\circ} 008430$ of 1993 resolution from the Colombian Health Ministry were fulfilled. This study had a low risk and followed the ethical principles established in the Helsinki declaration and we asked for permission to the ethics committee of the Pontificia Universidad Javeriana.

\section{Blood samples biochemical analysis}

The blood samples were taken through venipuncture from patients that fasted no less than 10 hours. The endpoint enzymatic method was used for measure the total serum HDL and total cholesterol, kinetic techniques for urea and creatinine. All tests were done with the proper quality control through standard spectrometry. The plasma total homocysteine levels were measured with fluorescence polarization immunoassay, FPIA in the IMX System. Mild hyperhomocysteinemia is defined as above $15-30 \mu \mathrm{M}$ and moderate levels ranging from 31 to $100 \mu \mathrm{M}$ [9]. Hypercholesterolemia was defined as cholesterol levels $>240 \mathrm{mg} / \mathrm{dl}[10]$.

The paraoxonase activity was measured by spectrophotometry, monitoring the hydrolysis rate, and the $\mathrm{p}$-nitrophenol produced in the reaction. The mixture included $1 \mathrm{mM}$ of Paraoxon, $1 \mathrm{mM}$ of $\mathrm{CaCl}_{2}$ Buffer, $50 \mathrm{mM}$ of glycine $(\mathrm{pH} 10)$ and it was added to $0.020 \mathrm{~mL}$ of serum. The $\mathrm{p}$-nitrophenol molar extinction coefficient (Aborbance: A405) was $\varepsilon: 180500$ $\mathrm{M}-1 \mathrm{~cm}-1$. PON1 activity was expressed in $\mathrm{U} /$ $1 ; 1$ unit is equivalent to $1 \mu \mathrm{mol} / \mathrm{min}$ of $\mathrm{p}$ nitrophenol.

\section{Genetic analysis}

The DNA was extracted from the whole sample according to salting out method [11]. PON1 genotypes were determined by PCR amplification and restriction fragment length polymorphism analysis. PCR reactions contained $0.5 \mu \mathrm{l}$ from each primer, $12.5 \mu \mathrm{l}$ goTaq Green Master Mix (Promega, Madison, USA) 50 ng DNA (Total: $25 \mu \mathrm{l}$ ). 35 cycles of amplification: 3 min at $95^{\circ} \mathrm{C}$ followed by 30 s at $95^{\circ} \mathrm{C}, 30$ s at specific primers annealing temperature $\left(55.4^{\circ} \mathrm{C}\right.$ for Q192R and $53.4^{\circ} \mathrm{C}$ for $\mathrm{L} 55 \mathrm{M}$ ) and 30 s at $72^{\circ} \mathrm{C}$ with a final extension of $5 \mathrm{~min}$ at $72^{\circ} \mathrm{C}$ were performed. PCR amplification for $\mathrm{L} 55 \mathrm{M}$ was 
performed using the following Primers: Forward 5' GAAGAGTGATGTATAGCCCCAG 3' and Reverse 5' CTCACAGAGCTAATGAAAGCC $3^{\prime}$. The amplification products were observed in polyacrylamide gel $12 \%$ and it was stained with ethidium bromide. The PCR product was digested with 5U enzyme Hsp92II (Promega, Madison, USA) and it resulted in $166 \mathrm{pb}$ for the WT (LL), 143 pb y $23 \mathrm{pb}$ (MM) and $166 \mathrm{pb}, 143 \mathrm{pb}$ and $23 \mathrm{pb}$ (ML). On the other hand, the PCR amplification for Q192R was performed using following primers: Forward 5'TATTGTTGCTGTGGGACCTGAG'3 and Reverse 5'CAAATCCTTCTGCCACCACT'3. The PCR product was digested with $5 \mathrm{U}$ enzyme Mbol (Promega, Madison, USA). The result for 192RR was $115 \mathrm{pb}$ and $40 \mathrm{pb}$, for 192QQ was 28 $\mathrm{pb}, 40 \mathrm{pb}, 87 \mathrm{pb}$ and for the heterozygote $(192 \mathrm{~L}$ and 192Q) 28pb, 40pb, $87 \mathrm{pb}$, and $115 \mathrm{pb}$. The fragments were separated by electrophoresis on $12 \%$ high solution polyacrylamide gel and revealed by silver nitrate staining.

\section{Statistical analysis}

Continuous variables were compared with the nonparametric Mann-Whitney $U$ test. The X2 test was used to compare the categorical variables. An exact binomial test was performed for hyperhomocysteinemia. PON192 and PON55 polymorphisms were analyzed assuming a dominant and recessive model. The analysis was performed in Epidat v.3.1, Stata v.9.1 and Graphpad v.6. The alpha value was 0.05.

\section{Results}

The study population was composed by 16 unrelated patients with ACS $(8$ men and 8 women; median age: 66 years, range: 48-74 years). The control group was composed by the same amount of healthy people with the same gender (median age: 58 years; range: 46-78, years).

Table 1 shows the differences between the median values of the variables studied in patients and controls. There was not found a significant difference between the median age of patients and controls $(\mathrm{p}<0.0700)$. A significant difference between cases and controls in serum levels of HCY $(p<0.0001)$ was found, which turned out to be higher in the patients. The binomial exact test for hyperhomocysteinemia showed statistical differences between cases $(62.5 \%)$ and controls $(6.25 \%)$ ( $\mathrm{p}<0.0001)$ No statistically significant differences were found in the serum levels of the other variables studied (HDLc, APO A1 and PON1).

Table 1. Demographic and clinical characteristics of population

\begin{tabular}{|c|c|c|c|c|c|}
\hline & \multicolumn{2}{|c|}{$\begin{array}{l}\text { Controls }(n=16 \\
\text { sex) (m/f) } 8 / 8\end{array}$} & \multicolumn{2}{|c|}{$\begin{array}{l}\text { Patients }(n=16 \text { sex) } \\
(\mathrm{m} / \mathrm{f}) 8 / 8\end{array}$} & \multirow[t]{2}{*}{ p value } \\
\hline & Median & Rank & Median & Rank & \\
\hline Age (years) & 58 & $46-78$ & 66 & $48-74$ & 0.0700 \\
\hline $\begin{array}{l}\mathrm{HDLC} \\
(\mathrm{mg} / \mathrm{dl})\end{array}$ & 49.5 & $34-56.7$ & 38.35 & \begin{tabular}{|l|}
$34-$ \\
101.58 \\
\end{tabular} & 0.1806 \\
\hline $\mathrm{HCY}(\mu \mathrm{M})$ & 10.275 & $\begin{array}{l}6.13- \\
15.2 \\
\end{array}$ & 16.635 & \begin{tabular}{|l|}
$13.6-$ \\
20.23 \\
\end{tabular} & $\begin{array}{l}<0 \\
0001 \\
\end{array}$ \\
\hline $\begin{array}{l}\mathrm{APO} \text { Al } \\
\text { (mg/dl) }\end{array}$ & 149 & $70-222$ & 126.5 & $89-175$ & 0.3554 \\
\hline $\begin{array}{l}\text { PON } 1 \\
(\mathrm{U} / \mathrm{i})\end{array}$ & 157.85 & $\begin{array}{l}42.55- \\
684.87 \\
\end{array}$ & 185.331 & \begin{tabular}{|l|}
$73.05-$ \\
483.97
\end{tabular} & 0.2067 \\
\hline
\end{tabular}

Nota:HDLc: High-density lipoprotein cholesterol; HCY: Homocysteinc; APOA1: Apolipoprotcin Al; PON1: paraoxonase 1.

The subjects were classified according to whether they were homozygous or heterozygous for the two polymorphisms (Q192R and L55M). Nevertheless, the three categorical variables were later grouped into two groups that classified the subjects according to a dominant or recessive model. In addition, Hardy-Weinberg equilibrium test showed that the genotypes in both groups were in equilibrium (Table 2).

Table 2. Allele and genotype frequencies for L55M and Q192R polymorphisms in cases and control group

\begin{tabular}{|c|c|c|c|c|c|}
\hline & \multicolumn{2}{|l|}{ Controls } & \multicolumn{2}{|l|}{ Cases } & \\
\hline & Number & Frequency & Number & Frequency & \\
\hline \multicolumn{6}{|c|}{ PON1 L55M } \\
\hline LL & 9 & 0.5625 & 8 & 0.5 & $\begin{array}{l}\text { Genotype p } \\
\text { Value }\end{array}$ \\
\hline LM & 2 & 0.125 & 6 & 0.375 & 10.000 \\
\hline $\mathrm{MM}$ & 5 & 0.3125 & 2 & 0.125 & $\begin{array}{l}\text { Allelic p } \\
\text { Value }\end{array}$ \\
\hline $\mathrm{L}$ & 11 & 0.6875 & 14 & 0.875 & 0.4386 \\
\hline $\mathrm{M}$ & 7 & 0.4375 & 8 & 0.5 & \\
\hline \multicolumn{6}{|c|}{ PON1 Q192R } \\
\hline$Q Q$ & 3 & 0.1875 & 5 & 0.3125 & $\begin{array}{l}\text { Genotype } \mathrm{p} \\
\text { Value }\end{array}$ \\
\hline $\mathrm{QR}$ & 10 & 0.625 & 8 & 0.5 & 0.8166 \\
\hline $\mathrm{RR}$ & 3 & 0.1875 & 3 & 0.1875 & $\begin{array}{l}\text { Allelic p } \\
\text { Value }\end{array}$ \\
\hline$Q$ & 13 & 0.8125 & 13 & 0.8125 & 0.3173 \\
\hline $\mathrm{R}$ & 13 & 0.8125 & 11 & 0.6875 & \\
\hline
\end{tabular}


According to tables 3 and 4 none statistically significant results were found for the PON L55M polymorphism. However, for Q192R polymorphism, when the homozygous RR genotype was grouped with the heterozygous group, statistically significant differences were obtained for the variable of plasma levels of homocysteine $(\mathrm{p}<0.0234)$. Higher levels of Hcy were found in the subjects with the $\mathrm{R}$ allele as can be seen in Table 3. HDLc and APOA1 levels were also evaluated and no statistically significant differences were found for any of the polymorphisms.

Table 3. Plasma homocysteine levels and L55M and Q192R polymorphisms in cases and control group

\begin{tabular}{|c|c|c|c|c|c|c|c|}
\hline \multirow[b]{2}{*}{ Polymorphism } & \multirow[b]{2}{*}{ Genotype } & \multicolumn{3}{|l|}{ Cases } & \multicolumn{3}{|c|}{ Controls } \\
\hline & & $\begin{array}{l}\text { Median } \\
(\mu \mathrm{M})\end{array}$ & $\begin{array}{l}\text { Rank } \\
(\mu \mathrm{M})\end{array}$ & $\begin{array}{l}\mathrm{p} \\
\text { Value }\end{array}$ & $\begin{array}{l}\text { Median } \\
(\mu \mathrm{M})\end{array}$ & $\begin{array}{l}\begin{array}{l}\text { Rank } \\
(\mu \mathrm{M})\end{array} \\
\end{array}$ & \begin{tabular}{|l|}
$\mathrm{p}$ \\
Value
\end{tabular} \\
\hline \multirow{2}{*}{ M dominant } & $\mathrm{M} / \mathrm{ML} / \mathrm{M}$ & 15.835 & $\begin{array}{l}13.6- \\
20.23\end{array}$ & 0.4945 & 10.8 & $\begin{array}{l}6.21- \\
15.2 \\
\end{array}$ & 0.6338 \\
\hline & $L / L$ & 17.72 & $\begin{array}{l}14.12- \\
18.88\end{array}$ & & 8.69 & $\begin{array}{l}6.13- \\
14.78\end{array}$ & \\
\hline \multirow{2}{*}{ L dominant } & $L / L L / M$ & 16.44 & $\begin{array}{l}13.6- \\
20.23\end{array}$ & 0.8116 & 9.91 & $\begin{array}{l}6.13- \\
14.78\end{array}$ & 0.9548 \\
\hline & $\mathrm{M} / \mathrm{M}$ & 17.115 & $\begin{array}{l}16.03- \\
18.2\end{array}$ & & 10.8 & $\begin{array}{l}6.21- \\
15.2\end{array}$ & \\
\hline \multirow{2}{*}{ Qdominant } & $Q / Q Q / R$ & 16.03 & $\begin{array}{l}13.6- \\
20.23 \\
\end{array}$ & 0.1575 & 9.91 & $\begin{array}{l}6.13- \\
15.2\end{array}$ & 0.9464 \\
\hline & $\mathrm{R} / \mathrm{R}$ & 18.66 & $\begin{array}{l}15.64- \\
18.88\end{array}$ & & 10.64 & $\begin{array}{l}8.42- \\
10.8\end{array}$ & \\
\hline \multirow{2}{*}{$\mathrm{R}$ dominant } & $\mathrm{R} / \mathrm{R} Q / \mathrm{R}$ & 18.2 & $\begin{array}{l}6.13- \\
14.78\end{array}$ & 0.0234 & 9.91 & $\begin{array}{l}6.13- \\
14.78 \\
\end{array}$ & 0.4593 \\
\hline & Q/e & 14.5 & $\begin{array}{l}13.6- \\
18.2\end{array}$ & & 12 & $\begin{array}{l}6.21- \\
15.2\end{array}$ & \\
\hline
\end{tabular}

Table 4. PON1 activity and L55M and Q192R polymorphisms in cases and control groups

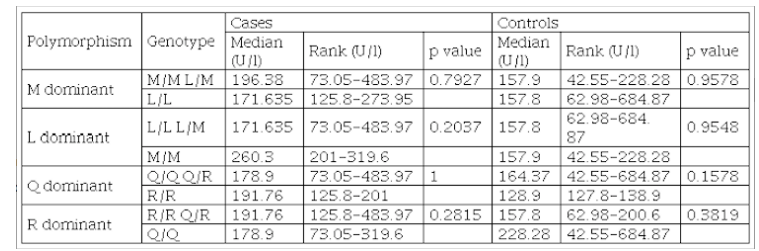

As seen in tables 3 and 4 , none of the other variables studied (HDLc, HCY, APOA1, and PON1 levels) showed significant differences. There were not any significant differences for the frequencies of PON1 haplotypes for cases and controls, as can be seen in table 5 .

Table 5. PON1 haplotypes frequency for cases and controls

\begin{tabular}{|c|c|c|c|c|c|c|c|}
\hline Variables & Haplotypes & Controls-number & Controls-frequency & $\mathrm{n}$ & Fatients-frequency & $\begin{array}{l}\text { Odds ratio } \\
(95 \% \text { CI) }\end{array}$ & value \\
\hline $\begin{array}{l}\text { Haplotype } \\
1\end{array}$ & $Q-L$ & 9 & 0.5635 & 11 & 0.6875 & $\begin{array}{l}0.54 \\
0.17-174)\end{array}$ & 0.789 \\
\hline $\begin{array}{l}\text { Haplotype } \\
2\end{array}$ & $Q-M$ & 6 & 0.375 & 7 & 0.4375 & 0.89 & 1.000 \\
\hline $\begin{array}{l}\text { Haplotype } \\
3\end{array}$ & $R-L$ & 10 & 0.625 & 10 & 0.625 & $\begin{array}{l}105 \\
0.36-305)\end{array}$ & 1.000 \\
\hline $\begin{array}{l}\text { Haplotype } \\
4\end{array}$ & $R-M$ & 5 & 0.3125 & 4 & 0.25 & $\begin{array}{l}1.40 \\
(0.33-5.79)\end{array}$ & 0.728 \\
\hline
\end{tabular}

\section{Discussion}

The cardiovascular disease is one of the principal mobility and mortality causes in the world and in Colombia is the principal cause of death [12]. Homocysteine levels result from the interaction between genetic and environmental factors, such as polymorphism in genes that participate in its metabolism and nutritional factors, respectively The increased levels of plasma total homocysteine $(\geq 15 \mu \mathrm{mol} /$ 1), hyperhomocysteinemia, is an independent risk factor for the cardiovascular disease (coronary artery disease and stroke), deep vein thrombosis and peripheral artery disease, increasing the risk of coronary artery disease even reaching the double in some populations. [9]

It has been estimated that approximately $20 \%$ of the coronary artery disease in the general population is attributed to hyperhomocysteinemia. Our results agree with the literature, since we found higher homocysteine levels with significant differences between the case and control groups. $62.5 \%$ of the hyperhomocysteinemic subjects had coronary arterial disease and only one control subject had hyperhomocysteinemia (6.25\%). Even though the atherosclerotic and thrombotic effects of the hyperhomocysteinemia have not been clarified yet, several possible damage mechanisms have been described: Oxidative endothelial injury, destruction of the vascular matrix, coagulation disorders, inhibition vasodilator and antithrombotic effect of nitric oxide, platelet activation, increase in lipid peroxidation, protein homocysteinylation, glutathione peroxidase activity decrease and increase in the oxidative stress $[13,14]$.

One of the endothelial damage mechanisms of the total plasmatic homocysteine or its metabolites implicate production of homocysteine thiolactone, which reacts with the lysine residues of the proteins disrupting its structure and function. On the other hand, paraoxonase is a multifunctional enzyme, degrades the oxidized LDL and has homocysteine thiolactonase activity, that hydrolyzes the 
homocysteine thiolactone to homocysteine [15] (Figure 1).

Figure 1. Factors that increase homocysteine

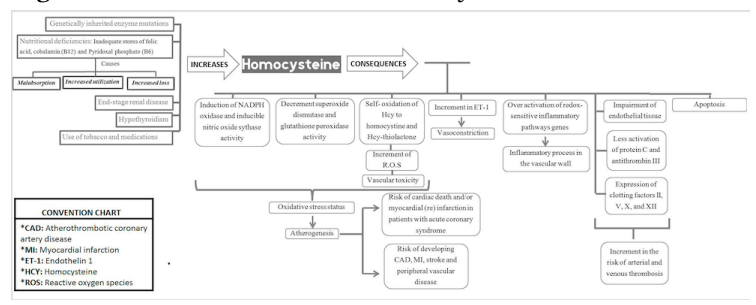

An increase of the homocysteine levels has been related to the severity of the cardiovascular disease, possibly due the decrease of the homocysteine thiolactonase/paraoxonase activity. Koubaa et al. [16] reported an inverse relationship between the homocysteine thiolactonase activity and the number of vessels affected, which were related with the PON1 polymorphisms, as well. The genotypes RR and MM were associated with a higher homocysteinetiolactonase activity and the genotype MM was more frequent in the subjects with coronary artery disease than in the control group, but without any relationship to the severity.

The association between the PON1 activity and the cardiovascular risk is controversial [15]. The PON1 activity is important, due its contribution to the HDL antioxidant function and its protective properties, that have been described, related to the development of the atherothrombosis. PON1 hydrolyzes the peroxides and lactones in LDL and HDL protecting the macrophages from oxidation, and participates in the endothelial homeostasis and the homocysteine thiolactonease activity described previously [17].

Contradictory findings have been reported regarding an association between PON1 polymorphisms, Q192R and L55M, and the coronary disease. The reason of this discrepancy is yet unclear, but it is possibly caused by differences in sample size, frequency of the polymorphisms in the population, and the study population. The biological mechanisms by which these polymorphisms could be associated to the disease are not clear yet and it is needed to develop more investigation trying to elucidate if paraoxonase is involved in preventing the lipid oxidation in the circulation and if there are other mechanisms involved in the physiopathology of the coronary artery disease [18]. For instance, it has been reported that Palestinian population have a higher frequency of the coronary disease and higher mortality associated than its Jewish population counterpart, with a higher frequency of diabetes and lower HDL levels. Based on the evidence, Gugliucci et al. decided to study other risk factors in Palestinian population, including PON1 activity and Q192R polymorphism frequency. The authors reported lower levels of PON1 activity and a lower genotype RR frequency with significant statistic differences, compared to the Jewish population, suggesting that these findings could explain, partly, the higher risk for cardiovascular disease [17]. Kallel et al. [18] found a higher $\mathrm{R}$ allele and RR genotype frequency in subjects with myocardial infarction, reporting an association between these factors and an increase in the risk for this pathology in Tunisian population. Other investigators, in India, found an association between the $\mathrm{R}$ allele and the coronary disease, as well. Although this change has been associated with a higher PON1 enzymatic activity, there have not been found any statistically significant difference related to the oxidized LDL levels, suggesting that other antioxidant factors could have an important role in LDL oxidation [19]. In a Finnish population of young adults an inverse relationship between PON1 activity and LDL ox levels were documented, supporting the evidence that suggests that PON1 activity regulates LDL oxidation. Furthermore, they found a lower PON1 activity in subjects with a QQ genotype (with statistically significant difference). However, there was no evidence associating this genotype with LDL ox levels. This evidence also suggests the importance of other factors [15] (Figure 2). 
Figure 2. Factors affecting the PON1 activity taken

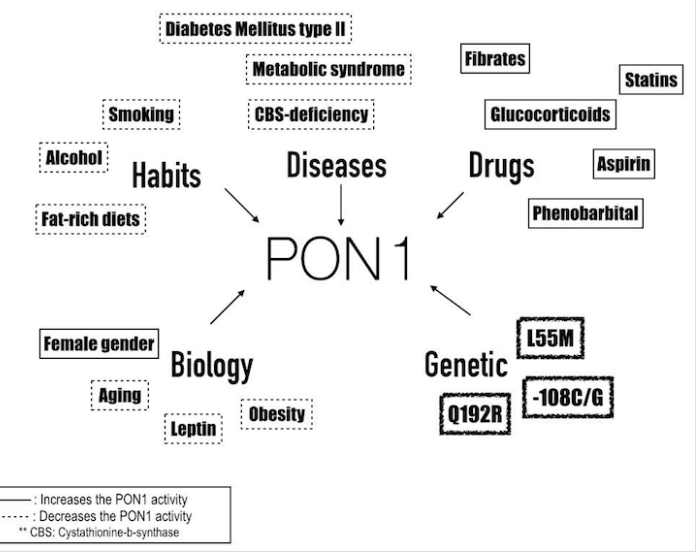

Wang et al. [20] performed a metaanalysis assessing 88 studies about the effect of Q192R, L55M and C-107T of PON1 gene and S311C of PON2 gene in 24702 subjects with coronary artery disease and 38232 controls. They found an increased risk for those individuals who carried the $\mathrm{R}$ allele (OR: 1,11; IC95\%: 1,05-1,17), without statistically significant difference between homozygotes and heterozygotes.

The 192Q (OR: 1,71; IC95\%: 1,0-2,8, p: 0,03) and 55M (OR:1,56; IC95\%: 1,1-2,3, p:0,03) alleles have been associated with a higher mortality risk at 10 years caused by ischemic heart disease with an allelic dose effect [21].

Finally, the evidence found in the literature regarding the role of PON1 activity and PON1 gene polymorphisms in the acute coronary syndrome and related pathological conditions are controversial, possibly due the different methodology in the studies and the different factors involved. About our results and according to the literature, it is possible that 192R variant, both in homozygote and heterozygote status, is associated with survival to acute coronary events, reason why it could be more frequent in studies such as ours, that have been performed on living subjects with background of this disease. Biologically this effect could be explained because the higher enzyme activity of PON1 reported on the literature, associated to the presence of this genetic variant. This higher activity could decrease the homocysteine thiolactone levels and could have a protective effect to hyperhomocysteinemia. In this sense, the presence of the variant would be a modulator of the severity and the mortality risk. Other effect that should be considered is a better response to the statins. This has been reported on subjects that carry this genetic variant $[16,20,21]$. Certainly, it is necessary to perform studies assessing this hypothesis and increase the sample size of our study to achieve a more accurate evaluation of the results.

In conclusion, the research in cardiovascular disease has accomplished to identify a few risk factors, such as arterial hypertension, obesity, metabolic syndrome, diabetes, hypercholesterolemia and a sedentary lifestyle. However, the identification of new risk factors offers opportunities to develop more effective prevention strategies and alternative treatments for these conditions [22]. Regarding the hyperhomocysteinemia as a cardiovascular risk factor, it has been postulated that an increase in vitamin B12 and folate intake could decrease the associated risk, since the deficit of these vitamins is an important cause of the increased homocysteine plasma levels [14]. It has been reported a better response to the statin treatment for carriers of the 192R allele, with increase of HDL levels. Additionally, nutritional factors such as vitamin $\mathrm{C}$ and $\mathrm{E}$ could increase PON1 activity, although this possibility should be evaluated in subsequent studies. On another hand, studies in vitro suggest that resveratrol could induce the PON1 gene expression [21].

\section{Acknowledgements}

The authors thank to Vicerrectory of Investigations of the Pontificia Universidad Javeriana and the patients. Project entitled "Relación entre HDL y Apo A-1 con la actividad de la enzima Paraoxonasa I y los polimorfismos Q192R y L55M del gen PON1 en pacientes hiperhomocisteinemicos" ID PPTA No. 00006196 and the hotbed of research "Investigación en enfermedades genéticas de origen metabólico” ID PPTA No. 6560. 


\section{References}

1. Hamm CW, Bassand J-P, Agewall S, Bax $\mathrm{J}$, Boersma $\mathrm{E}$, Bueno $\mathrm{H}$, et al. Guía de práctica clínica de la ESC para el manejo del síndrome coronario agudo en pacientes sin elevación persistente del segmento ST. Rev Esp Cardiol [internet]. 2012;65(2):173.e1-173.e55. Available from: http://www.revespcardiol.org/conten idos/static/avance_guias/Guia2012_3.pdf.

2. Ministerio de Salud y Protección Social, Colciencias. Guía práctica clínica para el síndrome coronario agudo [internet]. Bogotá; 2013. Available from: https://www.medicosgeneralescolom bianos.com/images/Guias_2013/gpc_17pro f_sal_sca.pdf

3. Secretaría de Salud. Guía de práctica clínica diagnóstico, estratificación y tratamiento de pacientes con síndrome coronario agudo sin elevación ST. México; 2010.

4. Porth CM. Fisiopatología: salud-enfermedad. Un enfoque conceptual. Bogotá: Editorial Médica Panamericana; 2006.

5. Rosales M de los AA. Guía para diagnóstico y tratamiento de las personas con síndrome coronario agudo. San José : Editorial Nacional de Salud y Seguridad Social; 2013.

6. Antoniades C, Antonopoulos AS, Tousoulis D, Marinou K, Stefanadis C. Homocysteine and coronary atherosclerosis: from folate fortification to the recent clinical trials. Eur Heart J. 2009;30:6-15.

7. Perła-Kaján J, Jakubowski H. Paraoxonase 1 and homocysteine metabolism. Amino Acids. 2012;43:1405-17.

8. Companioni O, Rodríguez Esparragón F, Fernández-Aceituno AM, Rodríguez Pérez JC. Genetic variants, cardiovascular risk and genome-wide association studies. Rev Esp Cardiol. 2011;64:509-14.

9. Bermúdez M, Briceño I, Gil F, Bernal J. Homocisteína y polimorfismos de cistationina $\beta$ sintasa y metilentetrahidrofolato reductasa en población sana de Colombia. Colomb Med. 37:46-52.

10. Prieto K, García-Robles R, Bernal J, Bermúdez M. Análisis descriptivo de los niveles de homocisteína, polimorfismos C699T, C1080T y 844Ins68pb de la CBS, C677T de la MTHFR y otros factores de riesgo cardiovascular en una población colombiana con síndrome coronario agudo. Univ Med. 2015;50(4):322-34.

11. Miller SA, Dykes DD, Polesky HF. A simple salting out procedure for extracting DNA from human nucleated cells. Nucleic Acids Res. 1988;16:1215.

12. Instituto Nacional de Salud. Boletín Observatorio Nacional de Salud [internet]. 2013 dic 9;(1). Disponible en: http://www.ins.gov.co/lineas-de-accion /ons/boletin\%201/boletin_web_ONS/bolet in_01_ONS.pdf

13. Santilli F, Davì G, Patrono C. Homocysteine, methylenetetrahydrofolate reductase, folate status and atherothrombosis: A mechanistic and clinical perspective. Vascul. Pharmacol. 2016;78:1-9.

14. Bawaskar HS, Bawaskar P himmatrao, Bawaskar PH. Homocysteine and cardiovascular system. Int Res J Pharm Sci. 2015;1-7.

15. Kresanov P, Vasankari T, Ahotupa M, Kaikkonen J, Hutri-Kähönen N, Juonala $\mathrm{M}$, et al. Paraoxonase-1 and oxidized lipoprotein lipids: The cardiovascular risk in young finns study. Atherosclerosis. 2015;241:502-6.

16. Koubaa N, Nakbi A, Hammami S, Attia N, Mehri S, Ben Hamda K, et al. Association of homocysteine thiolactonase activity and PON1 polymorphisms with the severity of acute coronary syndrome. Clin Biochem. 2009;42:771-6.

17. Gugliucci A, Menini T. Paraoxonase 1 and HDL maturation. Clin Chim Acta. 2015;439:5-13.

18. Kallel A, Sediri Y, Sbaï MH, Mourali MS, Feki M, Elasmi M, et al. The paraoxonase L55M and Q192R gene polymorphisms 
and myocardial infarction in a Tunisian population. Clin Biochem. 2010;43:1461-3.

19. Lakshmy R, Ahmad D, Abraham RA, Sharma M, Vemparala K, Das S, et al. Paraoxonase gene Q192R \& L55M polymorphisms in Indians with acute myocardial infarction \& association with oxidized low density lipoprotein. Indian J Med Res. 2010;131:522-9.

20. Wang M, Lang X, Zou L, Huang S, Xu Z. Four genetic polymorphisms of paraoxonase gene and risk of coronary heart disease: A metaanalysis based on 88 case-control studies. Atherosclerosis. 2011;214:377-85.

21. Regieli JJ, Jukema JW, Doevendans PA, Zwinderman AH, Kastelein JJ, Grobbee $\mathrm{DE}$, et al. Paraoxonase variants relate to 10 -year risk in coronary artery disease: Impact of a high-density lipoprotein-bound antioxidant in secondary prevention. J. Am. Coll. Cardiol. J Am Colleg Cardiol. 2009;54:1238-45.

22. Roever L, Reis P. Screening for peripheral arterial disease: An update. J Vasc Med Surg [internet]. 2015;3:197. Available from: https://www.esciencecentral.org/jour nals/screening-for-peripheral-arterial-disea se-an-update-2329-6925-1000197.php?aid $=54124$ 